PART THREE

NEW SUBJECTIVITIES AND UNOFFICIAL IDEOLOGIES 
Lars Gjelstad - 9789004261778

Downloaded from Brill.com04/26/2023 01:18:14AM via free access 
CHAPTER SEVEN

\title{
WORLDS OF SPARKLING LIGHTS: POPULAR MUSIC AND YOUTH CULTURES IN SOLO, CENTRAL JAVA
}

\author{
Lars Gjelstad
}

\section{Introduction}

In his The Religion of Java, Clifford Geertz described the emergent 'youth culture' of the 1950 s as 'the most vital element in contemporary Indonesian society' (C. Geertz 1960:307-8). It is associated with 'a group of restless, educated, urban young men and women possessed of a sharp dissatisfaction with traditional custom and a deeply ambivalent attitude toward the West' (C. Geertz 1960:307). According to Geertz there is a close connection between their strong national identity and their appreciation of popular songs, orchestras, movies, novels and other popular forms belonging to what Geertz calls 'the national-art complex' (C. Geertz 1960:302-3). These popular forms are regarded as national because they are not confined to the island of Java; they are expressed in the Indonesian language and they are mainly spread across the archipelago through the radio, movies and magazines (C. Geertz 1960:302-3).

Neither Geertz nor others have, to my knowledge, provided any substantial ethnographic accounts of the first waves of youth cultures in Java. From his fieldwork in Surabaya in the early 1960's, James Peacock (1968:102) briefly notes that 'rock ' $n$ ' roll or mambo-samba-like music played on electric guitars and bongo drums is a pervasive and audible part of youth culture in Surabaja'. Peacock then mentions that he at a circumcision ceremony was astonished by the contrast between the refined ethos of elderly Javanese men and the rather expressive aesthetics of a rock 'n' roll band performing there. 'Such music', Peacock comments, 'does seem to break down the formality of traditional etiquette' (Peacock 1968:102). The decisive significance of the rise of pop music for the restructuring of self and the flattening of Javanese hierarchies has been most thoroughly argued by James Siegel:

With the rise of popular music the connection between speaking well, acting well, and a totalized hierarchy is broken. In its place there is one's "own" 
language, the language of "expression" [...]. [P]opular music depends entirely on taste (selera), a notion new to Java (Siegel 1986:230).

The new phenomenon of taste corresponds with the emergence of a new 'social type' in Java - the teenager (Siegel 1986:203). Teens, in Indonesian called remaja, are allegedly defined by having certain tastes and aspirations (Siegel 1986:204). The expressiveness of youth is further associated with Low Javanese (ngoko), the 'natural' language of children and the language that surfaces, for example, when losing one's self-control ${ }^{1}$ (Siegel 1986:22).

Siegel's considerations of youth' changing conceptions of agency is important and stimulating. However, his analysis relies on a highly essentialised category of remaja. While these representations offer valuable insights into the discursive formation of youth, it ignores the complex and shifting ways in which youths actively co-create their own cultural worlds. These worlds should in my view also be studied 'in their own right' (Wulff 1995). ${ }^{2}$ The aim of this chapter is to demonstrate that this paradigm shift in youth studies may offer a fresh approach to the study of popular music and its relationships to both new and old social formations of the Malay world. Given the increased demand for cultural autonomy among Javanese youth, which of course also links them up with new structures of power, my argument is that popular music and youth cultural forms in general play a vital role in an ongoing restructuring of authority and agency in Java. This is for example noticeable in a rapidly spreading discourse exalting the value of self-confidence (percaya diri), not least articulated in contemporary popular music. Below I discuss the importance of this notion for the formation of youth subjectivities by focusing, among others, on how popular music encourages young people to playfully explore new textures and colours of their personality by offering a language for articulating the uniqueness of their selves.

1 The way personal and expressive styles of teenagers relate to the formality of Javanese etiquette and state rhetoric shares patterns with Bettina David's account in this volume on how the seducing corporeal rhythm of dangdut is considered by cultural elites as childish and symptomatic of the instinctual desires of the uncontrolled masses.

2 The attempt here to grasp 'the present' (Caputo 1995) of particular youth counters representations of youth merely as 'incomplete adults' found in conventional socialisation theories (Wulff 1995). Such theories are prevalent in the ethnography of Southeast Asia, and Bali (Bateson and Mead 1942) and Java (H. Geertz 1961) in particular. Even Siegel's comparison of the sociality and agency of urban teens of the 1980 s with those of traditional Javanese builds uncritically on Hildred Geertz's ethnography of socialisation practices in a small East-Javanese town in the 1950s (Bråten 1995:228-9). 
This chapter is an ethnographic account of the cultural worlds in which some young urban Javanese consumers of pop music live. It focuses primarily on how popular music is received and appropriated in everyday life by particular networks of youths localised in the city of Solo, Central Java. In order to explore how the uses and experiences of popular music are embedded in broader cultural styles and to identify how these styles are contingent upon situated cultural practice, I will contrast an upperclass and rather opulent 'clubbing community' with a gang of high school students playing guitar at their roadside hangout. I further describe how some members of this latter gang of high school students, which initially started as a fan club of the popular Indonesian artist Iwan Fals, began to experiment with house-music and Ecstasy (locally known as 'tripping'), which became popular at Solo discothèques in the mid-gos. ${ }^{3}$ These boys found in Iwan Fals a voice that was critical to cosmopolitan lifestyles, and below I show how this perspective influenced the boys' moral framing of their increasing involvement with global youth trends.

In the second part of this chapter I describe some features of a cultural field that evolved in Solo as elsewhere in urban Indonesia in the late 199os. It is associated with a worldwide form of dance music, called clubbing, and takes place at various cafés, often at the major hotels. This new cultural form is termed dugem, short for dunia gemerlap, which can be translated as 'a world of sparkling lights'. It refers to the use of spotlights and other visual effects that go with the music. From the cafés my young informants bring the music and its cosmopolitan atmosphere back into their private bedrooms, where they also prepare themselves for performances at the dance floor. The taste and competence acquired in these private spaces feed back into the cafés by way of dance performances and by requests for their favourite songs played by local and national Top 40 bands. ${ }^{4}$

The development of local youth scenes is increasingly influenced by global electronic media such as MTV programs in dialogue with local managers, event organizers, sponsors and various entertainment venues. I further pinpoint the significance of local tastemakers to the circulation of popular music across local arenas as well as to the local unfolding of

3 The gang of high school students was a main focus during 10 months of fieldwork in 1996, and it was also frequently revisited in the course of three periods of field studies between 2001 and 2005. It was also in these latter periods I came into contact with the network of clubbers.

4 Although charts have been lacking for a long time in Indonesia, the term 'Top 40' emerged at the youth scene in Solo with the rise of the above mentioned live performances at cafés. 
broader youth cultural practice. Since the uses of pop music always are embedded in what Holland et al. (1998) depict as historical contingent and socially enacted cultural worlds, musical activities cannot be sharply isolated and delimited. The task is rather to elucidate ways in which experiences of music are linked up with specific networks of social relationships (S. Cohen 1993:135), and to describe how the uses and meanings of pop music are embedded in broader circuits of youth cultural spaces and practices (Saldanha 2002:340).

\section{Sugaly: A Gang of 'Savage Children'}

After a few days of fieldwork in Solo in 1996 I passed a group of high school students sitting at a traditional Javanese snack bar (wedangan) by the city's main road. A boy, named Roni, ${ }^{5}$ shouted hello mister after me, and all of a sudden I find myself seated among them. The location near the bustling centre made the wedangan their favourite gathering spot. Some of the boys took turns playing the guitar while the rest sang along with much eagerness. Their favourite artist was Iwan Fals, whom they praised for his simplicity, honesty, solidarity as well as for his critique of the New Order government. An earlier generation of youth had actually established this gang $^{6}$ in the early 1980's as a fan club of Iwan Fals. These tattooed male youths had allegedly played the guitar most of the day, and despite their evocations of a delinquent (gali) style, they were not, unlike some other gangs at the time, looking for trouble. The name they had invented for their gang was Sugali, taken from a title of a song written by their hero. ${ }^{7}$ Sugali is an acronym for 'suatu gabungan anak liar', meaning 'a bunch of savage children'. The present generation that I sat with had changed the name Sugali inherited from their predecessors to Sugaly in order to set their personal mark on it and to make it hip.

5 Roni soon became my main informant when I thankfully accepted his and his parents' invitation to live with them in their home during my stay in Solo. This family has also been my hosts in subsequent periods of fieldwork.

6 The term 'gang' is a translation of the Indonesian 'genk', which commonly refers to peer groups with a certain delinquent image (drinking, fighting and racing). The term is used by the boys themselves.

7 'Gali' has connotations to 'a gang of street toughs' (Echols and Shadily 1989) and is synonymous with prèman (gangster). The word 'liar' connotes to be wild in the sense of uncivilized and primitive. Although portraying street toughs, the song 'Sugali' implicitly asks Indonesian youth not to join such gangs. The Sugaly boys I met in 1996 did, with lots of irony however, identify themselves with a gali ethos, including elements such as tattoo, drugs, street fighting, prostitution, and being an enemy of the police. 
A brief look at the lyrics of the song Sugali (1978) may help us to better grasp some of the atmosphere they are playing with:

Voi ... voices from the news, Written in the newspaper, About a male person, Who goes in and out of jail, Becoming someone wanted by the police, dar ...der ... dor, The sound of a gun, (belonging to) a 'gali' considered a firecracker, With no feeling of fear, Possessing magic making him invulnerable to gunfire, With his head more and more in the clouds, Watch the street thugs [Sugali] dancing at a, Low-class prostitution complex, Passionately working overtime until the morning, Having finished banditry wasting the money of Satan, Dig....did.....dug.

In contrast to the lifestyles of the youths hanging out at hotel bars and cafés, which will be described in later sections, this song deals with a gang- and banditry ethos related to rather low-class entertainment centres.

The foremost manner in which the Sugaly boys appropriated a gali behaviour was by motorbike racing (trek-trekan), which became a trend among affluent local youth around 1990. Most of these trendy 'gangsters' had their own motorbike, and the vehicles were objects of much attention. Their engagements in illegal motorbike racing did also represent an opposition to the police, who obviously represented the arbitrary and corrupt nature of New Order rule. 'When the police has gone to sleep, we use the street for racing', one of the boys explained.

Another important part of their collective identity was their construction of a particular secret language (prokem $)^{8}$ based on what they claim to be the Arabic language. They are thus making use of an already existing idiom for social differentiation in Indonesia. Most members of Sugaly were students at a Muhammadiyah high school where Arabic is taught as part of their religious instruction. Since their invented vocabulary mostly refer to activities forbidden by religion, such as sex and drinking, the function of Arabic as a social diacritica is here somewhat reversed. Their rather ironic use of Arabic to create a distinct collective youthful identity may therefore also be read as a local articulation of tensions between Islam and popular youth cultures - as well as an opposition to the world of schooling. ${ }^{9}$

8 See Chambert-Loir 1984; Murray 1991:104; Sahertian 2002.

9 An example of how musical elements became emblematic for their gang is the way they creatively incorporated the name of one of their favourite bands, Humania, into their exclusive slang (prokem Sugaly). Once we were gathered at their regular meeting point, one of them took the initiative to a drinking session by shouting 'sroop' (allegedly an Arabic word), another immediately answered 'Humania'. I was confused by this answer and since this occurred after several months in the field, they were rather surprised that 
From their basecamp the Sugaly members made several excursions into the urban landscape. In one of the first evenings I spent with them, a couple of girls dropped in and asked if anyone would like to accompany them to Discotheque Freedom. Two of the boys jumped on their motorbikes and the girls followed. The remaining boys eagerly told me that these girls were delinquent (gadis nakal). According to the boys, there were many bad girls in Solo nowadays because of the stress and frustrations that came with the 'global era'. ${ }^{10}$ They also believed that most of such girls came from broken homes.

With his song Frustrasi (Frustration) Iwan Fals ${ }^{11}$ has helped to circulate the term broken home and the message that children become delinquent because their parents are too busy with themselves to take care of their offspring. In fact, some of the Sugaly boys explicitly said they were hanging out because their parents were busy. According to Iwan Fals, 'a frustrated generation is 'disgusted watching dad, mum always going out'. The lyrics then continue:

There are things that, Don't make sense, Mum is busy searching for bachelors, Daddy is busy looking for young girls, Consequently I'm dejected, I better, Fantasize about, Becoming a big person like Hitler, The famous ...

The Sugaly boys themselves often framed their own engagements with emerging youth cultural styles in terms of cultural models of human development (with their hidden assumptions about the authority and agency of youth). The song describes how children who are neglected at home begin fantasizing about becoming really big persons (orang besar), persons that nobody can ignore. ${ }^{12}$ The Indonesian 'besar' means 'big' and is synonymous with the Javanese gedé, which is found in the expression

I had failed to notice the Sugaly way of saying 'up to you'. The Indonesian band Humania became popular with the song Terserah (Up to you)', and the boys would now substitute the name of the band with the name of this song whenever they would like to say 'up to you'.

10 These girls were also referred to as 'experimenting girls' (perek, an acronym for perempuan eksperimental). Such girls, I was told, liked to smoke cigarettes, wear mini skirts and practise free sex.

${ }^{11}$ When writing this chapter Iwan Fals is still catching up with the national music scene; he won the 'Indonesia MTV Award 2003' for 'Best male vocalist'. And Solo Pos (27.01.2005) reports that the arrival of a joint concert tour by Iwan Fals and Slank to Solo February 15th 2005 is one of the big attractions to Solo youth that year.

12 Mulder (1992) claims that according to a traditional Javanese worldview, a strained relationship between parents and children is always regarded as the child's failure: 'The thought of 'bad parents' or 'faulty education' being modern inventions that have not (yet?) penetrated into the Javanese mind' (Mulder 1992:35). Whereas other ethnographers have reported that juvenile delinquency in Java is commonly seen as resulting from parents' 
Anak Baru Gede (ABG). This expression may be translated as 'child just become big' (Gjelstad 1998) or a 'child just grown up' (Sen and Hill 2000:49). Given the social dexterity of the Sugaly boys and their passion to explore the cityscape, they often referred to themselves as ABG. It is a highly ironic concept, and since it mostly refers to youth belonging to the middle- and upper classes, the concept plays upon a significant Javanese distinction between commoners, wong cilik, and the elite, the wong gedé (Sen and Hill 2000; Gjelstad 1998). The Sugaly boys themselves were of a mixed social background, most of them somewhere between the lower and middle classes. The fact that they had their own motorbike and were high school students, tells us as much of their aspirations as of their actual class position. The boys themselves played with middle class values and symbols, and they often identified themselves as ABG. The term exemplifies here how constructions of youth entail negotiations of class. It does also intersect with other dimensions of youths' uncertain relations to modern lifestyles, not least ethnic Javanese conceptions of maturation and upbringing. Tellingly, the name of the gang Sugali codifies the conventional metaphorical tying of children and lack of civility, linking the term wild (liar) with the term for child (anak).

\section{Negotiating Lifestyles through Popular Music}

Iwan Fals' ironical notes about young people's drive to become big and famous influence the Sugaly boys' articulations of the frustration and confusion that arise from their engagements with contemporary youth cultures. ${ }^{13}$ In 1996, one of the Sugaly boys said he used Iwan Fals' music as 'medicine' when he felt sad, confused or crazy. He further told that he tried to be a 'shadow theatre kid' (anak wayang), a phrase taken from the title of a song by Iwan Fals, meaning that he wanted to be like the wayang heroes who can differentiate the virtuous and upright from the immoral and foolish. With these references as a backdrop, he said he did not like popular youth trends such as tripping and motorbike racing, as he considered them too opulent and glamorous. He then referred to the song Ini si

neglect of their children and lack of harmony in the family (Guinness 1986:136-7), the popularity of the expression broken home signals that the authority of parents is increasingly questioned.

13 Such a bewilderment I think applies to Indonesian youths in general, which may also explain the popularity of the rather ironical phrase Anak Baru Gedé (ABG) as a general category for modern youth. A common critique of $\mathrm{ABG}$ is that they always want to create sensation and uproar (onar, héboh) with their assertive styles. 
Trendy (This is trendy) by Iwan Fals in which a modern-day obsession with trends is equated with the worshiping of one's 'self', with empty talk, with becoming the slave of desire, and with being afraid of the old-fashioned. In the next moment, however, the teenager disclosed his fantasies about having a VW Beetle and taking part in motor crossing, which were at that time popular symbols of a cosmopolitan lifestyle. With a dry smile, he admitted that he probably disliked the cosmopolitan lifestyle because he had no money, thus revealing an underlying uncertainty about his commitment to the frugal ideals he had articulated a minute earlier.

Although the subjectivities of youth have changed dramatically, the stories above suggest that youth may still experience the kind of ambiguity toward Western lifestyles that Clifford Geertz commented on four decades ago. Iwan Fals is a deft interpreter of such tensions, and my view is that the Sugaly boys, at a certain level, interpreted their complex experiences in terms of the narratives that Iwan Fals provides them. ${ }^{14}$

Iwan Fals was of course not the only kind of music the Sugaly boys listened to; Western rock bands such as Red Hot Cili Peppers and Guns n' Roses were for example very popular. In 1996 house music, in Indonesia commonly referred to as 'tripping', had also became popular. My main informant then, Roni, soon learned this style. He bought several tapes with house dance music, and he went to discotheques and danced to the latest hits, opening up his mind and body to songs like 'Digital stimulation', 'Phuck me, phuck me (sic)', 'You are so sexy', 'Work that pussy' and 'Ecstasy, Ecstasy'. He explicitly described this sort of music as 'crazy music'. House and techno are generally associated with the use of Ecstasy, which in turn seems to stand metonymically for a decadent generation. In the days before the national Independence Day in 1996, journalists and politicians warned that Ecstasy could be a serious threat to the nation's future. The police also reacted sharply to the new trend of house music and drug use, and almost every week the police closed down a discotheque after inspections. These media reports on the societal threat of youth tripping at discotheques evoke Stanley Cohen's notion of British youth as 'folk devils' (Wulff 1995:3).

Local meanings of tripping do also articulate with undercurrents of Javanese traditions. In 1996, youth in Solo frequently employed the metaphor of the buffalo (kerbau) when speaking of the unruliness of their generation, associating the stupid and whirring buffalo that has to be

14 In an article in The Eastern Economic Review, Margot Cohen (1991) refers to a thesis by Elena Zachnas on Iwan Fals arguing that the enormous popularity of Fals among youth is due to the exclusion of youth from national politics, suggesting that by articulating 'what they are afraid to say themselves', Iwan Fals's messages fill a vacuum. 
constantly herded with youth tripping at the discotheques. Teenagers' articulations of stress and frustration are, as already suggested, comprehensible in light of the emphasis placed on self-control and refined behaviour with in Javanese cultural traditions. To have stress signifies that one has not yet 'become human' (dadiwong), which is connected with the concept of having 'not yet become a Javanese' (durung Jawa) (H. Geertz 1961).

As James Siegel (1986) has remarked, teenagers' tastes, aspirations, and excitements are experienced as rough and strange by many Javanese. The Sugaly boys would frame their 'delinquent' practices by identifying them as part of a 'cultural stream of things crazy' (aliran gila-gilaan). The fact that they select normative categories of craziness (together with derogative categories such as stress and unruliness) from dominant discourses in Java to comment upon their cultural practices, demonstrates that they experience themselves as transgressing some cultural and normative boundaries.

I have pointed out that the Sugaly boys identify themselves as trendy and that expressing one's distinct personal style is highly celebrated. It is their unique personal and collective styles that define them as ABG and which marks them off from both poor kampung boys and the dry and clever students at school. However, while they highly rate individual idiosyncrasies, they also express a strong collective solidarity, for instance in the phrase 'one for all, all for one'. These values of friendship are perhaps most deeply expressed through collective drinking practices, which almost seem to take on ritualistic qualities. These drinking patterns include collecting money and sharing the shot glass and are usually organized by an improvised Bandar. ${ }^{15}$ The collectivistic quality of drinking together is also strengthened by the marked property of alcohol to open up minds and bodies to the joy of the moment. If one does not join these sessions, he should have a very good excuse.

My argument is that Iwan Fals' popularity to a large degree arises from his ability to articulate such social values which at least implicitly represent a critique of governments and schools. Iwan Fals' music then articulates an undercurrent morality which is already a constituent part of their multi-layered subjectivities. This is then turned, consciously or not, against state authorities, including a rigid and achievement-oriented educational system. Even if they as part of their identity as modern teens desire all kinds of new trends, these culturally defined desires stand in a

15 The bandar is a sort of croupier (Echols and Shadily 1989), and the person in charge of the cards in gambling is often referred to as a 'bandar', but it also refers to persons engaged with illegal retailing of alcohol or drugs. For example the Sugaly members would refer to a seller of ciu, inexpensive traditional liquor, as a bandar ciu. 
formative relationship to their moral dispositions and reflections. These tensions constitute a driving force in the dynamic evolution of youth cultural forms, finding its path for example into various 'indie movements'. I return to this issue in the last section.

The next step in my reflections on the variety of ways in which popular music take part in the dynamic unfolding of youth cultural practice, is a revisit to the Sugaly gang some 5 years after my first encounter, and describe some changes in their experiences of music and life.

\section{Revisiting Sugaly: Biography and Diversification of Musical Taste}

In 1996 my main informant, Roni, was playing in three different bands, and given his knowledge of popular music he became a kind of local hero among neighbours and classmates. When the cafés started to mushroom in Solo a few years later, he performed at several of these venues, which made him even more 'famous' among Solo youth. After graduating from high school and freed from the control of school authorities he could finally let his hair grow, which brought him closer to a rock 'n' roll imagery. When I met Roni again in 2001 he had moved to Jakarta for studies in classical guitar at the Jakarta Academy of Art (IKJ). In the suburb where he lived he played with several bands at a studio where he also took turns at the mix board. While he was a rather well known figure in Solo, he found it hard to 'get a name' in the capital. Nevertheless Roni now felt lucky and a bit proud for having been able to leave Solo and Sugaly, which he now characterised as rather destructive, as people there have no ambitions. While his friends at the academy certainly also had their excesses in life, they differed from his former Sugaly friends as they wanted to achieve a professional career. In a way Roni has been able to transform his hobby into a career, unlike most of his former Sugaly friends, who are either unemployed, low paid or studying at low-quality institutions.

Some of the Sugaly boys, especially the leader figures, have made the transition to adulthood less well and have become involved in drugs and gangster activities (gali, preman). It seems that some of the boys had difficulties in breaking with a lifestyle and a sense of self they had strived so hard to obtain in their teenage years; they may have been somewhat ensnared by their play with gangster images in their high school years. For some Bob Marley's music and his smoking habits became markers of that style. These boys, which now have become seniors vis-à-vis a new 
generation of Sugaly kids, took pleasure in saying that Iwan Fals had written many of his popular songs while smoking marijuana and they especially refer to the song Frustrasi, mentioned above, where he describes the eyes of a marijuana smoking persona, a certain 'Mr. Gelek'. Gelek is slang expression for marijuana. This reframing of Iwan Fals' music is another example of youths' active and shifting engagements with popular music.

The most remarkable change of musical orientation is that of Fahrid, the tough and sharp-witted boy who used to be the leader figure in 1996. In 2001, he told that he was tired of tripping and motorbike racing and rather preferred to relax. His explanation for this change of personality is that in the years of one's youth one usually has a taste for things coarse (keras), whereas one becomes more refined (halus) when one grows older. He now frequently visited a small village just outside Solo, where his father grew up, to drink ciu with some friends there. Some of them played kroncong (a small ukelele-like string instrument) with a repertoire ranging from characteristic kroncong music to Iwan Fals and Slank. Fahrid admitted that most of his Sugaly friends do not like kroncong, primarily because they are prestige-oriented and consider it as old-fashioned. Despite his friends' supposed dislike for kroncong ${ }^{16}$ I think Fahrid recognises in these musical practices some of the simplicity he and his friends formerly experienced when playing Iwan Fals and drinking tea or ciu at wedangan, their roadside basecamp.

In 2001, the Sugaly boys had to some extent been drawn into a café-oriented sociality that is known as dugem, partly because they realised that guitar playing, motorbike racing and gang fighting were not that trendy any longer. Due to lack of money they usually had to seek out cheaper places with no cover charge. Rather than ordering expensive individual drinks at the bar, which is common in the up-market places, young female hostesses will serve a mix of beer, vodka and Kratingdaeng (a popular energy drink) served in a jug poured into shot glasses. At some of these cheaper places, the boys will sing karaoke to their favourite music, including Terserah (Up to you) by Humania, Makan nggak makan asal kumpul (Even if there is not much to eat, it is important that we are together $)^{17}$ by

16 Kroncong music has criss-crossed class and ethnic boundaries in Indonesia (Becker 1975). Whereas its social and historical life is fascinating for all its complexity, the literature commonly describe its current reception among modern youth as rather lowbrow and olden (Lockard 1998:67).

17 This is an Indonesian translation of a Javanese proverb (Mangan ora mangan, nek kumpul), giving emphasis to interpersonal solidarity, often within kindred groups (Koentjaraningrat 1985:457). 
Slank, and of course their true favourite Sugali by Iwan Fals. This makes up a sociality quite distinctive to that of youth hanging out at luxury hotels and bars. This gap was occasionally marked on Saturday evenings when the boys suddenly might change their initial wish to seek out cafés and decide to drink ciu at their regular base camp, as this was less wasteful. Similarly, they sometimes repudiated the use of ecstacy because it was too expensive and bourgeois (borju). Occasionally, we went to a rather upperclass venue with an entrance fee, and where they served Western food such as fried potatoes and beer with individual glasses. On these visits, we had to negotiate carefully who should go with us, as we could only manage to collect the money needed to get five or six people in. This certainly represented a break with the inclusive and egalitarian ethos of Sugaly as it was manifest in collective rituals of drinking and guitar playing.

In the next sections I turn to a network of youth that managed to position themselves more at the centre of the new café culture associated with the phenomenon of dugem.

\section{Dugem: The Music of Cosmopolitan Youth}

As mentioned in the introduction dugem is a popular expression for a youth scene that evolved in urban Indonesia in the late 1990s. Dugem is a short for dunia gemerlap, which I have translated as 'a world of sparkling lights. While the term may refer to night life in general, it is largely associated with the musical practices taking place at the new cafés and bars in Solo. The music bar Musro at Quality Hotel is definitively the local centre.

At Musro DJs and live bands play hip-hop, techno- and house music, Indonesian and international pop music, and occasionally indigenous traditional and popular genres like dangdut.Dugem is commonly associated with DJ'ing and clubbing. In addition, my observations in Solo suggest that the performances of female vocalists in Top 40 bands are inspired by the aesthetics of MTV-mediated video clips, and that dugem therefore partly refers to the visual effects that go with these musical events. The rise in the popularity of dugem reflects a major aesthetic shift within transnational fields of popular music. In the early 1990s, Tony Langlois argued that ' $[\mathrm{t}] \mathrm{o}$ a larger proportion of the generation now in their teens, it is the DJ rather than the rock and roll guitarist who provided social and music role models' (in Bennett 2001:122). The electric guitar and the long hair have been replaced by Internet and MTV video clips and mp3. As 
Keith Howard notes, the influx of music videos has led to 'a vision of pop based on visuals, based on action and dance' (in: De Ceuster 2001). ${ }^{18}$

Local appropriations of these aesthetic forms relate to the reformation of youth subjectivity and sociality, which in turn articulate with co-existing cultural traditions in Solo. Dugem is an example of how young people construct new idioms. It is part of a new youth slang that also helps to articulate novel youth identities. These distinct identities are vital to the development of lifestyle-oriented national cultures, not the least of which is expressed in a high number of television soaps, where pop music also plays a vital role. I will argue that these novel cultural forms also inspire the construction of new categories of youth. When I conducted fieldwork in Solo in 1996, ABG was a popular term. Teenagers in Solo said it remained so until about 1999, when it was replaced by the term anak gaul. In the Indonesian language, anak means child while gaul means to be sociable. An anakgaul is a child skilful in social interaction, but the concept of gaul has also connotations to sexual intercourse (Echols and Shadily 1989:174). An anak gaul refers first of all to teenagers who are familiar with the most recent trends in, e.g. music, film, Internet, cellular phones, and who easily socialize with others, including the opposite sex, and who know the language of the youth, called bahasa gaul. In short, being gaul is to be a modern youth with money, taste and self-confidence. ${ }^{19}$ As I attempt to show throughout this chapter, what it means to be 'gaul' is always locally elaborated by particular youth in specific sites and in interaction with a diversifying mediascape, as well as in dialogue with local event organizers and other professionals in the field. The rest of the chapter considers how pop music is involved in such cultural dynamics.

\section{Entering the Worlds of Sparkling Lights}

In 1996 Roni's 12 year old brother, named Agus, had already began to fantasise about his future teenage life. He used to stay in his elder brother's

18 Emma Baulch (2002:223) has persuasively argued that the rather deregulated recording industry in Indonesia has been eclipsed by more regulated media, such as MTV and teen magazines. This situation may explain why Solo youth somewhat confusingly associate dugem with both underground club cultures and 'mainstream' pop images.

19 In my analysis, the term gaul has become indexical for a newly evolved taste that culturally defines, or discursively forms, a category of youth that has replaced remaja. Remaja appears today as a generic term for 'youth', including the mainstream or ordinary teenager. As with 'dugem', the meaning of 'gaul' is a dynamic one since it always has to be realized by particular youth in particular settings in a dialogue with a steadily diversifying mediascape. 
bedroom leafing through teen magazines. Once he was eagerly reading 'Hai', I asked him why he read such stuff, and he answered, without even taking his eyes away from the page, that he was 'searching for trends', adding that he was afraid of 'being left behind'. He was frequently seen dancing in his bedroom, which he transformed into a 'disco' by switching off the lights, playing his brother's House Dance Mix tapes, and imitating the distinct style of tripping by shaking his head and waving with a flashlight in his hand. I assume he was acting out some fantasies generated by his brother's stories about tripping and discotheques. Such events were one of many ways Agus was enacting his future position as a 'teen', and he was seemingly longing for the excitements he imagined a life as a teenager would bring with it.

Back then he was somehow taking his first steps into the worlds of sparkling lights. Later, as a high school student Agus began to write a diary about 'my lifestyle', 'my favourite movie', 'watching concert', 'ekspress my soul', 'my first kiss' and so on. The diary was very much about what he perceived to be his own decisive steps towards a great teenage life. It includes a preface where he states that he will never forget the great times of his life as a teenager. It is also a time where he will 'continuously search for his true and genuine self'. It is interesting that he understands the years of one's youth as a special time, as a period where one searches for one's true personality (Gjelstad 2005a). These diary notes reproduce a popular discourse of youthful self-exploration, and what is ethnographically significant about these articulations of youth is the way they contest those representations of youth implicit in Javanese notions of maturity and upbringing. The marginalization of youth implied in traditional Javanese socialization practices seems to accord with a general pattern of denying youth "full social personhood," which only adulthood will bring (James 1995:47). Despite an enduring exclusion of Indonesian youth from adult worlds, pop music helps to reassign the value of youth by conveying images of the ideal youthful life as passionate, amusing and unique. The cultural significance of youth' engagements with popular music in Java as elsewhere in the Malay world is further related to the growing importance of bedrooms as arenas for articulating personal identities.

\section{Popular Music and 'Bedroom Culture'}

When I met Agus again in 2001 he immediately showed me the bedroom where he was found tripping some 5 years ago. Now it had become, in his words, a 'dugem site' (tempat dugem). Full of pride he pointed at his new installation, a wire with blinking light bulbs fastened along the roof lists 
and a compact disc hanging from a string in the ceiling, which while rotating, reflects the lamplight in a way resembling the mirror ball and the flashing lights at discothèques and music bars. One of his bedroom walls were covered with surfing- and skating pictures. The rest of the rooms were completely filled with pictures of movie- and pop stars, among them two huge posters of US pop singer Jennifer Lopez. These sparkling images as well as his stereo rack are totally overshadowing his little shelf of textbooks. The iconicity of popular sonic landscapes exhibits exactly the musicality, interactivity, and multiplicity of meanings that are lacking in the authoritarian ethos of Indonesian schooling. By decorating his room as a place for dugem, Agus personalises a place that is also distinct and autonomous from the rest of the house.

When Agus and his friends gather in his room, they often play music filled with digital techno-sounds, including strange samplings and remixes, ${ }^{20}$ which they truly associated with dugem. It is amazing to see their active and corporal engagements with the music, and a salient feature of this cultural production is their visualization of these soundscapes through face mimicry and movements of arms, fingers and legs. I consider their modes of engagement, their selections and manipulations of musical elements, as a further development of the basic principle of cut ' $n$ ' paste that dominates contemporary electronic music. The boys will take out some sequences from the music, then simulate and modify it by exaggerating, simplifying or elaborating these sonic images.

The kind of events described above clearly function as exercises for their performances at cafés, where the ability to make funny movements on the dance floor is one of the defining characteristics of the 'funky' teenager. There is thus a constant circulation of elements across sites of cultural production. Sometimes, when the boys have their dugem performances in his bedroom, Agus will place himself close to the stereo rack and distribute a typed list of his music collection (which he usually uses to take up orders for his small recording company), and he asks his friends for requests, as is common in the cafés when Top 40 bands are playing. He also circulates the drinks menu that he has taken from the Music Room (Musro) at Quality Hotel. They then circulate glasses, pretending they are drinking 'Illusion', the most expensive drinks (200.00o Rp., i.e., about 30 USD), which is made of Vodka, Bacardi, Tequila, Dry Gin, Blue Curacao, Sambuca, Cointreau, and Orange Juice. Through playful cultural practice

20 Some of it was illicitly downloaded from the Internet for circulation among networks of acquaintances. 


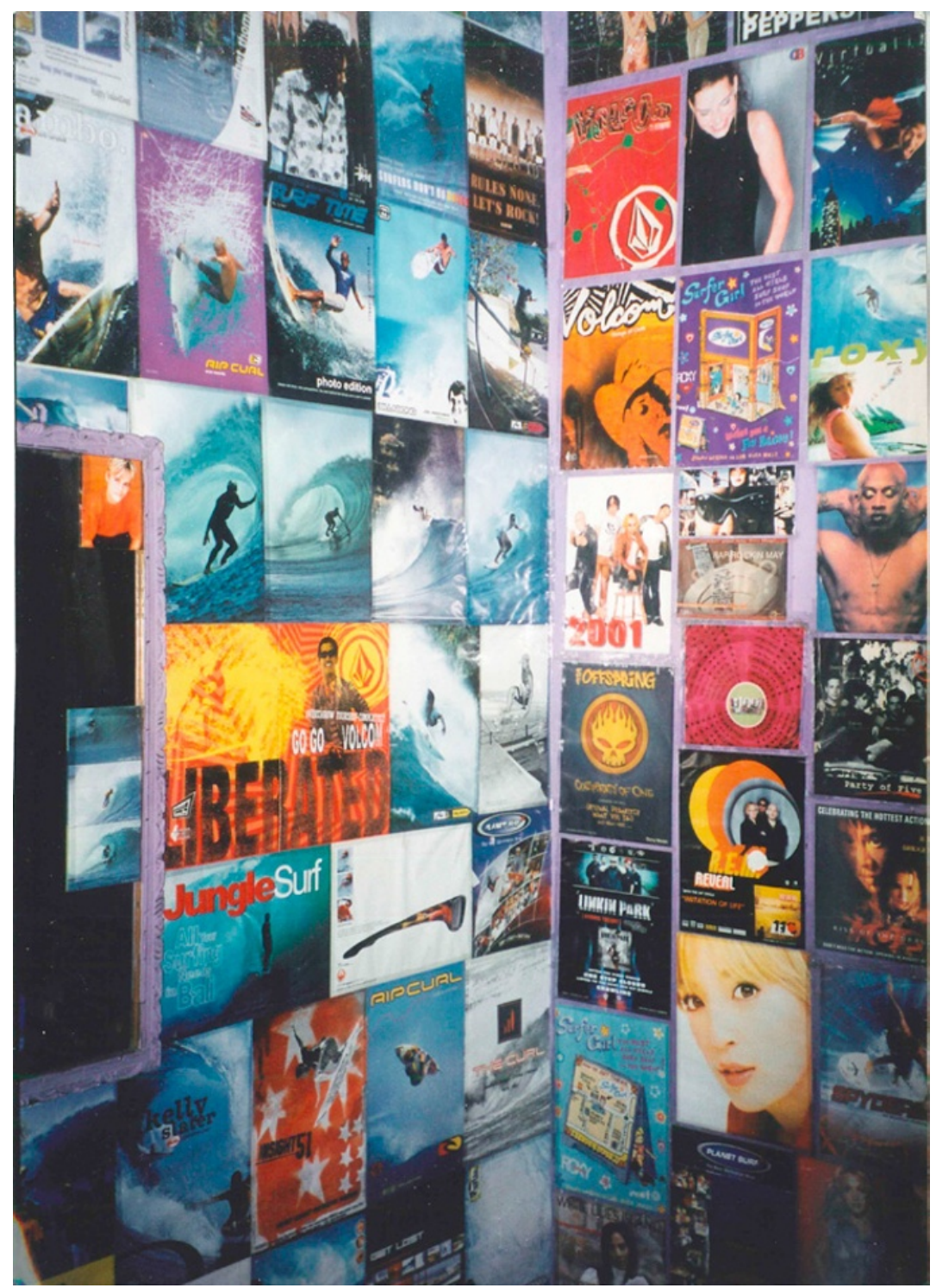

7.1. Bedroom of Agus (photo by author).

in the bedroom, the boys are creating cultural identities based on cultural models of cosmopolitan nightlife offered by the local music bar.

The bedroom was also the centre for his small 'recording company'. His personal stereo was plugged into a computer so he could download his favorite music on mp3 files from the Internet, copy them onto CDs or 


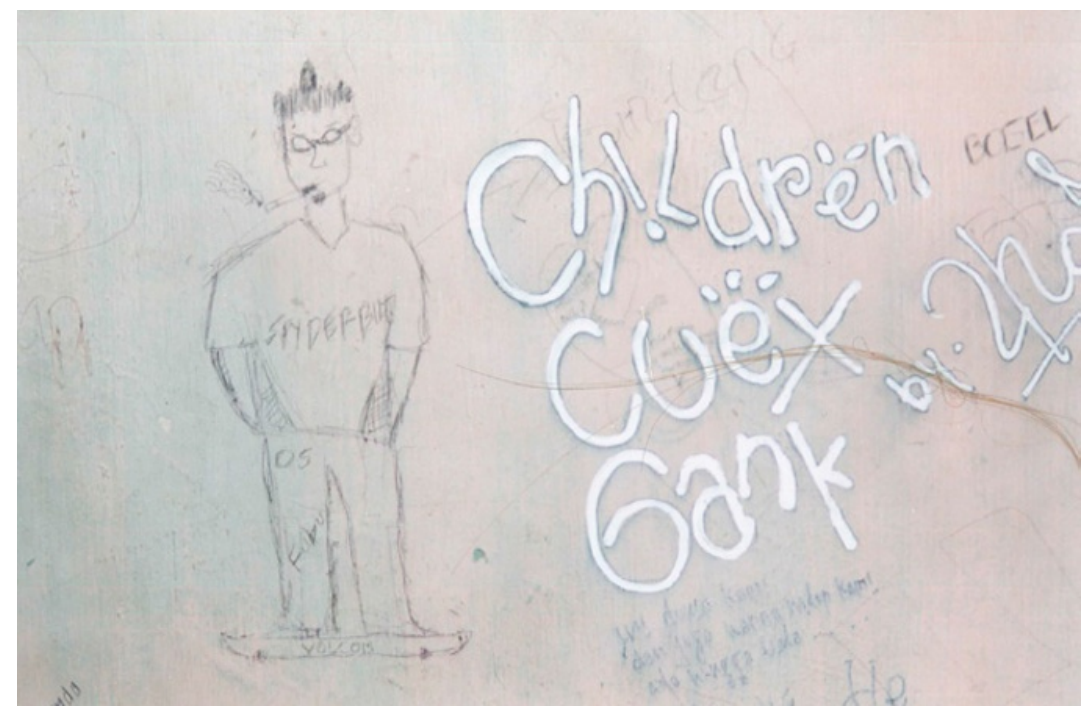

7.2. Bedroom wall of Agus' younger brother, with a drawing where he and his friends style themselves in skater imagery next to their gang name, an intersection of alternative masculinities (photo by author).

cassettes, and sell them to friends and classmates. The customers could also pick their own favourites from a list he had carefully designed on his personal computer. In addition to emphasising how youth identities and practices develop over time, the point here is that these bedroom practices have to be understood as moments in a wider 'circuit of the production, circulation and consumption of cultural products' (Johnson 1986-1987:46).

As Arun Saldanha (2002:340) has argued, it is exactly by following the informal circuits of youth cultural spaces and practices that one can discover particular ways in which local and global elements are plaited together in the ongoing musical practices of young people. This is what may be the first step in the exploration of what Chun and Rossiter refer to as the 'heterogeneous third space [...] that mediates the competing interests between the local and the global' - the juncture where 'an aesthetic refashioning of traditional and pop music genres emerge' (Chun and Rossiter 2004:5).

The self-decorated and self-expressing bedroom with a lockable door symbolises an increasing cultural autonomy of affluent youth and a parallel generational divide. The bedroom appears as a distinct cultural zone for instance in that Agus himself has written 'Gaul only' on his door. Words 
such as 'cuex', ${ }^{21}$ and 'top secret' are also scribbled there. In yet another indication of the importance of the bedroom as a site for the formation of personal identities, he had attached his name card to the door. The cultural space of the bedroom is also sonically marked: The first thing Agus will do when entering the room is to switch on his stereo, and in this sense he also makes his presence audible to family and neighbors.

\section{Soundtracks in My Life}

Consumption of popular music is indeed an essential part of the way Agus was colouring his teenage life. In the diary mentioned above, under a heading called 'soundtracks in my life,' Agus made a list of 16 songs that had a special meaning to him (April 200o). For every song, he wrote a sentence explaining what made it special. Among his favourites was Kiss me with Sixpence None the Richer (and taken from Dawson's Creek, one of Agus' favourite soap operas), which is associated with a particular romantic happening; 'my Valentine song from the moment I gave chocolate to Ella, and at the end, she kissed me'. Backstreet Boys', As long as you love me has become his 'sweet memory' from the time he got his first love letter. About the song Kita by Seila on 7, he writes that this is 'the favourite song of his school gang', and adds that it 'might be said to be our obligatory song.'22 This last example shows how popular music may become emblems of collective identities (similar to the role of Iwan Fals' music to the gang Sugaly).

The significance of these accounts lies in how the songs help to create a kind of 'memory world' (Halbwachs, in Munn 1995) by providing generalised narrative models of how to become and act like a teenager in relation to particular persons and places. As general templates, the love songs to which Agus refers in his diary structure not only his memories of and relations to particular local girls, but they also familiarize him with a broader figured world of girls and dating. Songs might thus prescribe models for how to, for instance, date a girl and what kind of feelings they should evoke. The pleasures and pains of locally situated dramas influence in turn the meanings of these songs. Such mediations of popular

21 Cuex is a modification of the word cuek, which means being indifferent or ignorant.

22 Agus successively became part of two other gangs in Solo. The first one was Durex (short for Dunia Remaja Cuex, translated as 'the world of indifferent teenagers'). After leaving Durex he managed to join a more renowned gang called CCG (short for Children Cuex Gang). Cuex is the gaul version of cuek, meaning indifference or lack of concern. 
music further impinge upon the way youths inhabit, navigate and make sense of their local environments by binding local scenes up with wider cosmopolitan centres through offering novel 'characters, plots, and textual forms' (Appadurai 1996:35).

Elsewhere (Gjelstad 2005a), I have described how Agus, when the diary was filled up with interesting stories from his own sparkling teenage life began to circulate the diary among his schoolmates. When some of them suggested that he should make a film of it he went through the stories in his diary and gave them headlines resembling typical titles of episodes in TV-serials such as Dawson's Creek. The film, he says, will become exciting because there will be lots of beautiful girls, luxurious cars, hotels, and of course dugem. As part of that project he begins to attach a soundtrack to some of the episodes. This is an example of mutual encompassment of popular songs and memorable moments framed by the conventions of televised drama. In the diary he also makes a list of the four rich, pretty and famous girls in Solo whom he frequently is hanging out with, and who, he says, 'are colouring my life and made my life rich with pretty women'. To each of these he has dedicated what he explicitly terms a 'memory song', and one of these is Lady Marmalade by the MTV diva Christina Aguilera. A further indication of his tying up of local personalities with global pop icons is that he downloaded pictures of Britney Spears and Christina Aguilera in navel-bearing tops and placed them side by side with his diary presentation of two of his famed acquaintances. There are significant relations here between Agus' media practices and his socializing with local girls.

Another example of the importance of popular music for the production of new forms of subjectivity is found at the end of Agus' diary, where he - in a mix of formal and informal Indonesian language ${ }^{23}$ - thanks not only God, his family and his dugem friends for what they have meant to him, but he also wants to thank MTV for having made him 'feel selfconfident and funky' (merasa pd dan funky). He also feels a need to thank Dawson's Creek, the American TV-drama, because the programs often have made his life more 'energetic', and for having introduced him to the 'beauty in the world'. These mass-mediated worlds offer what may be

23 The Indonesian language used in this diary contrasts sharply with formal language of education and politics. The former version is influenced by youth slang (e.g. bahasa $\mathrm{gaul}$ ) as well as interspersed with an English vocabulary. The choice of Indonesian - rather than Low Javanese (ngoko) - as the language of intimacy, is significant in light of Siegel's thesis about the relation of youth and language mentioned in the introduction to this chapter. 
called 'scripts for possible lives' as well as new 'resources for experiments with self-making' (Appadurai 1996:3).

Agus' assertion that mass-mediated popular forms have enriched his life and made him more self-confident ( $p d$ or pede from percaya diri, 'self confidence') is indicative of the importance of the cultural phenomenon of pede for the formation of youth subjectivities in Solo. In a highly hierarchical society it is significant that the younger generations embrace images of the autonomous person in control of the situation, images deriving from a range of mass-mediated popular forms, including pop music. The cases above thus epitomise the intervention of music industries in young people's experiences and understandings of their lives as teens. Yet, what it means to be a modern youth is always locally explored and negotiated in relations with significant others. In his diary, under the heading dunia gemerlap, Agus recollects his first encounter with the night life. In a sharp contrast to his elder brother Roni, Agus has from early childhood had a close relationship to his mother, who often hangs out at hotel bars. The following extract reveals how she influenced his entry into the worlds of sparkling lights:

This night I was about to fall asleep when I heard the sweet voice of my mother's calling. I saw she had already prepared herself for an evening with friends at a pub, as she often does after having worked all day... But this day was different, my mother asked me to go with her. At that time I was in the third grade at junior high school (SMP). I was invited to Hotel Novotel for a Top 40 music program targeted for young people and this was the first time I encountered what is called 'dunia gemerlap'.

The following paragraph shows how he immediately felt attracted to an aesthetics associated with dugem:

After I went there I started to feel a different atmosphere, and I just became aware that I had entered what is called night-life (dunia malam). To be honest, I felt comfortable there, and after that moment, every Saturday night, I have been searching for this kind of world. A few days later two friends of mine visited my house. They invited me to Dugem at Music Room at Quality Hotel, which is more often known as MUSRO. I agreed with their new way of spending the Saturday night. Later, night after night, and not only Saturday night, I spend my nights going 'cafe to café' and I have explored almost all the cafés in Solo. Finally, I got more and more friends with the same hobby and then we made a dugem community (komunitas anak anak dugem).

As these diary notes reveal, musical practices are embedded in broader dynamics of lifestyle-, identity-, and network formation. In the next paragraph Agus emphasises he and his friends' role in pioneering dugem at the local youth scene: 
At that time the cafés in Solo was not so lively as today, it might be said that it was we who pioneered the young people in Solo to spend the Saturday nights at cafés, afterwards, at every hang-out I often heard the words 'Musro, dugem'. This caused a new spirit to again search for a nightlife that was crazier than the clubs in Solo. Many in our community received information that the nightlife outside Solo was more hot, wild, and courageous than the clubs in Solo. Consequently, we went outside town to explore all the clubs all over the island of Java, beginning with Safir Club at Ambarukmo Hotel in Yogyakarta and as far as Astro Cafe in Semarang. At that time I never felt satisfied; to the contrary, 24 hours really felt too short, and the effects of nightlife such as glamorous lifestyles, social freedom and casual sex (gaya glamour, pergaulan bebas dan free sex) do not leave me even though I now is about to leave dunia gemerlap.

Once I discussed with Agus my experiences in 1996 with Sugaly and tripping, he insisted that Solo youths at that time were 'not yet funky'. In contrast to the new cafés, Agus and his friends regarded the discotheques in Solo as shabby and rather low class. ${ }^{24}$ Whereas Roni and his Sugaly friends in 1996 regarded tripping and the discotheques as rather trendy and different from the sort of places described in the song 'Sugaly', Agus and his friends tend to equate the discotheques with these low-class centres. Referring to the last sentence of the diary notes quoted above, these places seems to lack the glamour of what local youth now refer to as a borju lifestyle. $^{25}$ That Musro and the lifestyle of the people there were at the apex of a local hierarchy of youth cultural practices he got confirmed when the words Musro and dugem were to be heard in every hangout.

\section{Glimpses from the Local Dugem Scene}

In addition to Musro, Agus and his friends frequented a few other cafés in Solo featuring live bands playing Top 40 music. The bands are constantly interacting with the taste of their audiences. Female singers in sensual black shorts and tops are teasing their predominantly male audience, for instance, by singing out I'm so horny, horny, horny, the refrain of the song Horny by DJ Mousse T. (with Hot 'n' Juicy). Another popular song is Crazytown's

24 Agus himself distinguishes between dugem and tripping, referring to the latter when describing his visits to discothèques, which usually took place after the cafés closed.

25 This cosmopolitanisation of the music-oriented youth cultures in Solo certainly helps to legitimate, in cultural terms, the increasing wealth of indigenous Indonesians (see Heryanto 1999 and Baulch 2002). In my PhD dissertation (2009) I describe how Agus's classmates and neighbours openly contest the value of being borju, which in turn influences his own behaviour and reflection. 
Butterfly, a title that plays on a renowned brand of Ecstasy pills with a butterfly imprint on it. Dugem and butterfly are concepts that often go together in youth talk. Some of Agus' dugem friends explained that the use of the drug butterfly makes one 'comes closer to the music', join in easier socially, and become more emotional.

Agus' new friends, what he calls his 'dugem community', are all from rather upper-class families. They carry mobile phones, dress in cloths from a popular skateboard brand, and many of them have expensive cars as well. Their lifestyle practices are influenced by street and surf cultures, which in Solo are most significantly promoted by Planet Surf. This is the largest outlet of surf-, skate-, and streetwear in the city, promoting itself as 'The Next Generation Shop'. This fancy, highly decorated shop is fully stuffed with international brands, and here youth can hear the latest music hits as well as see videos showing pictures from popular surfing paradises all day long. Agus and his friends made frequent visits to this place, which obviously influenced their visual and sonic definitions of what it means to be gaul. This aesthetic also shares a pattern with that found in the cafés and music bars they regularly visit in Solo and in the neighbouring cities of Yogyakarta and Semarang.

When these boys go dugem at cafés, they request their favourite songs from the live band by filling out a form. The request sheets distributed at the tables do not only serve to modify the Top 40 repertoires and thus bring young people's taste more effectively into the orbit of popular music, but the presence of requests also gives these youth a feeling of being co-producers of the soundscape. Although less agentive than in their bedrooms, their practices at cafés and music bars inspire their musical practices at home.

The following observations from a visit I made with Agus and his friends to Musro at Quality Hotel during my last fieldwork (January 2005) reveal some characteristic aspects of dugem (and also some later changes in the scene). The first part of the program was much like what it used to be some years back, with a popular band, Delapan Band, from Bandung playing Top 40 music. One male and two female vocalists lead the show. The male vocalist wore black leather trousers and two female vocalists wore small black short pants (revealing a flap of their buttock), black boots, black top, with silver belts and silver chains. Their movements were quite sensual, occasionally simulating a striptease. The vocalists regularly came down across the dance floor inviting the guests, mostly young men, to dance with them or to sing along. The band played a mix of Western and Indonesian pop and rap - occasionally a dangdut song that always 
helped to energize the audience. As is common at such events, they also received requests from the audience.

After the first set, the MC (Master of Ceremony) introduced some games with prizes donated by the main sponsors of the event. Then he screamed to the audience, announcing a 'hot hot hot sexy dance' and asked the crowd to welcome the 'Go-Go-Girls.' ${ }^{26}$ Six girls entered the dance floor wearing only bikinis with their waists partly enveloped by a small towel, which they soon began to remove in a most seductive manner. Destiny Child's 'I loose my breath' blasted through the sound system, and the girls performed a dance that was actually inspired by the choreography found on the video clip to that popular song. All the guests had now gathered close to the stage. The Go-Go Girls were dancing daringly while touching vital body parts, bending their bodies down to the floor, jumping upon the speakers, and then sliding down with spread legs. Close to the stage, there was a swing pole and they took turns twisting and spinning around the pole.

After the session, Agus talked to one of the go-go girls, who was an acquaintance of a friend of his, and the following days he received numerous SMSs from her. He informed me that she was studying at a university in Yogya karta, whereas most of the other dancers were high school students. Agus', explanation for their willingness to perform in this rather controversial manner was that they just enjoyed dancing and the glamour, and that they really admire Britney Spears and similar pop celebrities. ${ }^{27}$ This not merely suggests the influence of the MTV-mediated female pop stars, but also how groups of urban Javanese teens strive to localise global trends and thus become themselves producers of popular youth culture. This certainly occurred in close dialogue with the corporate strategies of managers and event organizers.

After the 'go-go performance', the MC introduced DJ Arya Positiva. This Saturday night was one of the rare events in Solo where the DJ actually scratched vinyl records rather than playing and remixing CDs on a mixer board. When the DJ was about to fade out his last piece, the drummer of

${ }^{26}$ While Britney Spears, Christina Aguilera, Avril Lavigne, Jennifer Lopez and other MTV celebs, in the footsteps of Madonna, certainly inspire female youth in Solo, most Solo girls are critical of these local go-go girls. More research should be done on how various groups of teenagers respond to such images of female agency.

27 Another likely source of inspiration is the video clips accompanying Christina Aguilera's song Dirrty from her album Stripped. Although the Indonesian censorship committee banned this music video, many teens in Solo downloaded it from the Internet. Dressed in a miniskirt and a bikini top, the pop diva performs an erotic dance whose movements incessantly reveal her little red pants. As the title of her album suggests, the show clearly contains elements of stripping. 
Delapan Band began to jam along the deep bass lines of the techno beat. After a lengthy solo session, the Go-Go Girls came back on stage and tried to fall into the groove with their rhythmic movements - this time with an even more seductive repertoire. The most daring ones wrapped their legs around the pole and then leaned backward. Some of the girls also started teasing each other, followed by some bumping and grinding movements. When the band entered the stage for the last set, the female vocalists also incorporated some easy pole-dance work into their performance.

The relationship between audience and performers is an important dimension of the dynamic unfolding of music-oriented youth cultures in Solo. To that aspect of musical production we must add the work of managers (of bands, models and dancers), event organizers, local production companies, sponsors, and persons in charge of local bars and hotels to create new nightlife concepts, such as the one described above. This evening at Musro had several features that have become part of a steady transforming youth scene. Firstly, sexy dancing and fashion shows have become a common part of many events in Solo. Secondly, the DJ has become a central figure. The managers and event organisers in Solo look in turn to larger neighbouring cities such as Yogyakarta and Bandung for inspiration. These organisational structures are significant aspects of the development of the local youth scene as well as of the discursive formation of 'youth' (Gjelstad 2013).

\section{Contesting Dugem: Rave Parties and DIY-Cultures in Solo}

In 2003, Agus and his friends informed me that dugem and hanging out at cafés now was a bit outdated, and that the current trend in Jakarta was huge outdoor rave parties as well as private parties in villas. While Musro and some of the cafés in fact remained popular in 2005, I could observe several changes in the youth and music scene when I returned to Solo for a short follow-up fieldwork that year. Many of these innovations are created by an event organizer, which has become an increasingly important profession in urban Indonesia. In cooperation with sponsors and managers they are constantly developing new concepts in dialogue with the local markets which they themselves strive to enlarge (Gjelstad 2013).

Rave Parties are among the most spectacular of such events. The first one in Solo was arranged at Stadion Manahan in September 2004, and a second one was held at Hotel Lor In. The former staged five national DJs, as well as 'sexy dance'. Not surprisingly Agus and his friends joined the 
party, and Agus also made a documentary film of the event, which became part of his small recording business. For a long time Agus has dreamt about becoming a film director like his TV-soap hero Dawson Leery (Gjelstad 2005a). Agus also made documentaries of rave parties at Kaliurang, a hill resort some twenty kilometres north of Yogyakarta, as well as at Queen of the South Hotel \& Resort at Parangtritis. The Go-Go Girls described in the section above performed at the rave party in Kaliurang too. This performance occupied a central place in several of Agus documentary films. By re-producing the cultural productions of these sexy dancers, they became part of the glitzy life that he proudly presents as his own in the videos. The local celebrities that personify the cultural worlds of MTV-stars are no longer confined to his diary and bedrooms walls, but have now become available in a more up-dated medium and to a larger audience.

Agus has now also gained a position as a free-lance graphic designer and an event organizer in a local production house despite lacking formal training in the field. At daytime he studies Public relations at the local state university, but most evenings he is now busy designing posters, billboards, stickers and advertisement strips for new arrangements targeting youth. These arrangements were produced in cooperation with the local marketing office of the cigarette brand Sampoerna Mild Live. Through these practices, Agus managed to take a step further in the direction of creating a more professional role out of his hobby, including advancing from that of being an ordinary guest at cafés and music bars to becoming a co-organizer of the events taking place there. At one point during my last fieldwork trip he had started to fit up a multi-media studio in a vacant room adjacent to his bedroom. Its furnishing was inspired by the DIYdesign culture of the new distro.

The sudden rise in the popularity of distro, a shorting of distribution store, is related to another significant shift in Indonesian youth culture. This is a reorientation from hyper-commercialised brands such as those sold at Planet Surf in Solo to that of independent designers making t-shirts in small numbers (thus regarded as unique pieces) and distributing them at small shops. The designer, like the DJ, has become a new prominent kind of artist on the Indonesian youth scene. A distro is typically a modestly equipped locale and the initial capital requirement is accordingly low. Besides, the retailers usually need not invest in a large stock of goods since most designers are happy about having their pieces stored there for free. The solidarity among designers and distributors is also said to be high. They explicitly distance themselves from factory outlets and mass 
products and their business relies largely on extensive networks of acquaintances and friendship. ${ }^{28}$

As with the promotion of rave parties at rather isolated places outside town, the marketing of indie merchandises is usually based on word of mouth and by the circulation of stickers. The distro are run by people who are regarded as idealistic and who are reacting against the big international brands such as Billabong and Volcom. And teenagers in Solo tell me that 'Planet Surf' is not trendy anymore. The distro are centres of alternative cultures such as break-dance, skating, trash- and punk musicians. The designers and distro assistants are seen as creative and idealistic people who resist the cafés and dugem as well as Top 40 music. They rather prefer to hang out at the traditional snack bar or at the distro itself. These shops also sell 'indie' label records, magazines as well as a wide range of accessories, including those specifically targeted for punks, skaters, and other local youth scenes. The distro provides these practitioners with objects symbolising their particular lifestyles.

The spread of new indie cultures of which the distro functions as an important node entails contradictory processes. On the one hand, it represents an ideology countering the highly commercialised field of music, media, and clothing products. On the other hand, it quickly becomes coopted by larger companies. Local bands on the rise sign up with larger recording companies, and local skating heroes may eventually become sponsored by international skate-wear brands. In addition, high school students are prone to appropriate the 'indie' movements as just another trend, as a fad, and not for any idealistic reasons. This actualizes the position taken in this chapter that popular cultures represent important sites for negotiating social realities. Correspondingly, the multi-layered subjectivities of youth are formed within 'multiple imaginary terrains that contest, support or ignore one another' (Chun and Rossiter 2004:3). One pertinent question now is how teenagers' appropriations of various indie-movements will influence the creation of new identities and categories of Indonesian youth.

\section{Conclusion}

This chapter has showed that the uses of popular music are significant for the formation of young people's agency, and the ways in which youth

28 Two newspaper articles confirm and expand the picture provided by my informants in Solo: 'Dari indie jadi sakti' (Kompas, 22.08.2003) and 'Pilih baju lebaran di FO atau distro?' (Kompas, 07.11.2004). 
conceptualize personhood and sociality. The importance of the study lies in the fact that we still lack research dealing with the diverse interpretations and uses of popular music among localized networks of ordinary youth living in rapidly transforming Malay worlds. A study of popular music and youth cultures in a former Javanese court city, now highly integrated in a national and transnational political economy, is interesting since contemporary youths' ideals of explicitly expressing their emotions, needs and personalities in many ways break with deeply grounded Javanese conceptions of respect, etiquette, seniority and hierarchy (C. Geertz 1960; Siegel 1986).

The style of the gang I discuss in the first part of the chapter clearly represents such a break. This is already apparent in the name they had invented for the gang, Sugaly, which means a 'bunch of savage children'. Geertz's notes on the ambiguity of youths' orientations to the 'West' seems still to be prevalent, which for instance was expressed in the category of youth dominant at the time of my fieldwork in 1996. This term, Anak Baru Gede (ABG), literally means a 'child just grown up' (Sen and Hill 2000:49), and is of a rather ironical character. It is my argument here that popular music plays an essential role in the varying ways and means whereby localized youth internalise and recontextualize the elements and imagery structures of youth culture. The Sugaly boys had appropriated the title of one of Iwan Fals' songs as the name of their gang. Their engagements with his music did also influence their moral framing of their rising involvements in a range of youth cultural practice, such as dancing to the electronic sound of 'house' (locally known as 'tripping'), which became popular at Solo discothèques in the mid-9os. I also contend that the local semantics of tripping articulated with undercurrents of Javanese traditions emphasising the value of etiquette and self-control.

The second part of this chapter is an ethnographic portrayal of a musicoriented cultural field that evolved in urban places on Java in the late 1990s. This new cultural form is termed dugem, short for dunia gemerlap, which can be translated as 'a world of sparkling lights'. It refers to the use of spot lights and other visual effects that goes with the music. 'Dugem' is a multivocal and shifting term. While it was primarily associated with electronic music presented by DJs at major music bars, it now commonly refers to the live music performed by Indonesian bands at the many cafés that mushroomed in Solo in the late 1990s. These performances are inspired by the aesthetics of MTV-mediated video clips, but the evolution of the local youth scene is as well influenced by local networks of event organizers and entertainment centres. I further show the significance of 
local tastemakers in the circulation of popular music across local arenas. The local dugem community that I describe in this chapter is an example of a music-oriented youth cultural practice that is closely associated with the cosmopolitanisation of Solo and the emergence of a consumer-oriented national culture. From the cafés my young informants bring the music and its cosmopolitan atmosphere back into their private bedrooms. The taste and competence acquired in these informal spaces are then fed back into the cafés by way of dance performances and by requesting their favourite songs from local and national Top 40 bands.

This development of an aesthetic shaped in a discourse of personal preferences represents a radical break from the aesthetic regimes of Javanese high cultures. James Siegel (1986:229) makes the point that karawitan (traditional Javanese court music) is seen as embodying cosmological images to which the individual could tune itself into, but where it is irrelevant whether the listener likes the sounds or not. Although Siegel's (1986) reifications of 'Java' is problematic, I find it fruitful to contrast high Javanese aesthetic regimes with how popular music encourages Solo teenagers to playfully explore new textures and colours of their personality by offering a language for articulating the uniqueness of their selves.

\section{References}

Appadurai, A. Modernity at large: Cultural dimensions of globalization. Minneapolis: University of Minnesota Press, 1996.

Bateson, G. and M. Mead. Balinese character: A photographic analysis, Vol. 2. New York: New York Academy of Sciences, 1942.

Baulch, E. 'Alternative music and mediation in late New Order Indonesia', Inter-Asia Cultural Studies 3:219-34, 2002.

Becker, J. 'Kroncong, Indonesian popular music', Asian Music 7:14-9, 1975.

Bennett, A. Cultures of popular music. Buckingham: Open University Press, 2001.

Bråten, E.'Riddles of inverted being: A case of self and fellowship formation in Yogyakarta, Java. $\mathrm{PhD}$ thesis, University of Bergen, Norway, 1995.

Caputo, V. 'Anthropology's silent "others": A consideration of some conceptual and methodological issues for the study of youth and children's cultures', in: Vered Amit-Talai and Helena Wulff (eds), Youth cultures: A cross-cultural perspective, pp. 19-42. London: Routledge, 1995 .

Chambert-Loir, H. 'Those who speak prokem', Indonesia 37:105-17, 1984.

Chun, A. and N. Rossiter. 'Introduction: Cultural imaginaries, musical communities, reflexive practices', in: Allen Chun, Ned Rossiter and Brian Shoesmith (eds), Refashioning pop music in Asia: Cosmopolitan flows, political tempos and aesthetic industries, pp. 1-14. London: RoutledgeCurzon, 2004.

Cohen, M. 'Born to be meek', Far Eastern Economic Review (24 October): 38-40, 1991.

Cohen, S. 'Ethnography and popular music studies', Popular music 12:123-38, 1993.

De Ceuster, K. 'On the social phenomenon of Asian pop (Interview with Keith Howard)', IIAS Newsletter 26:2, 2001. 
Echols, J.M. and Hassan Shadily. Kamus Indonesia-Inggris: An Indonesian-English dictionary. Third edition. Jakarta: Penerbit PT Gramedia, 1989.

Geertz, C. The religion of Java. Glencoe, IL: Free Press, 1960.

Geertz, H. The Javanese family: A study of kinship and socialization. Glencoe, Ill: The Free Press, 1961.

Gjelstad, L. 'Coming of age in a time of globalisation: Global trends and local heroes in "New Order" Surakarta'. Paper, Workshop 'Consumption and Lifestyle in Java', Passau, 5-6 June 1998.

- "I will never forget the time of my youth": An analysis of a teenager's diary and its cultural contexts'. Paper, Workshop 'Youth and Identity in Java', Salatiga and Yogyakata, 12-15 January 2005a.

— - 'Youth and cultural complexity in contemporary Indonesia: The cultural production of youth at intersections of homes, schools and peer groups in the city of Solo, Central Java'. PhD thesis, University of Bergen, Norway, 2009.

—. 'Young Professionals in Urban Java: Youth Cultures and the Imaginary Forms of the 'New Economy". In Bråten, E. (ed.) Embedded entrepreneurship: market, culture, and micro-business in insular Southeast Asia. Leiden: BRILL, 2013.

Guinness, P. Harmony and hierarchy in a Javanese kampung. Singapore: Oxford University Press, 1986.

Heryanto, A. 'The years of living luxuriously: Identity politics of Indonesia's New Rich', in: Michael Pinches (ed.), Culture and privilege in capitalist Asia, pp. 159-87. London: Routledge, 1999 .

Holland, D., W. Lachicotte Jr., D. Skinner and C. Cain. Identity and agency in cultural worlds. Cambridge, Mass.: Harvard University Press, 1998.

James, A. 'Talking of children and youth: Language, socialization and culture', in: Vered Amit-Talai and Helena Wulff (eds), Youth cultures: A cross-cultural perspective, pp. 43-62. London: Routledge, 1995.

Johnson, R. 'What is cultural studies anyway?', Social Text 16:38-80, 1986-87.

Koentjaraningrat. Javanese culture. Singapore: Oxford University Press, 1985.

Lockard, C.A. Dance of life: Popular music and politics in Southeast Asia. Honolulu: University of Hawai'i Press, 1998.

Mulder, N. Individual and society in Java: A cultural analysis. Yogyakarta: Gadjah Mada University Press, 1992.

Munn, N. 'An essay on the symbolic construction of memory in the Kaluli gisalo', in: Daniel de Coppet and André Iteanu (eds), Cosmos and society in Oceania, pp. 83-104. Oxford: Berg Publishers Limited, 1995 .

Murray, A.J. No money, no honey: A study of street traders and prostitutes in Jakarta. Singapore: Oxford University Press, 1991.

Peacock, J.L. Rites of modernization: Symbolic and social aspects of Indonesian proletarian drama. Chicago: The University of Chicago Press, 1968.

Sahertian, D. Kamus bahasa gaul. Jakarta: Pustaka Sinar Harapan, 2002.

Saldanha, A. 'Music, space, identity: Geographies of youth culture in Bangalore', Cultural Studies 16:337-50, 2002.

Sen, K. and D.T. Hill. Media, culture and politics in Indonesia. Oxford: Oxford University Press, 2000.

Siegel, J.T. Solo in the New Order: Language and hierarchy in an Indonesian city. Princeton, New Jersey: Princeton University Press, 1986.

Wulff, H. 'Introducing youth culture in its own right: The state of the art and new possibilities', in: Vered Amit-Talai and Helena Wulff (eds), Youth cultures: A cross-cultural perspective, pp. 1-18. London: Routledge, 1995. 